\title{
Studies of Child Perspectives in Methodology and Practice with 'Osallisuus' as a Finnish Approach to Children's Reciprocal Cultural Participation
}

\author{
Liisa Karlsson
}

\begin{abstract}
This article discusses the methodology and practices involved in studies of child perspectives, which is an orientation of research and action focusing on children's perspectives and social participation as a cultural phenomenon. The objective of this orientation is to examine children's and youth's views and their ways of operating and acting as well as the data they produce. It includes listening to children's varied signals and information through multiple methods and analysing their experiences, views, actions, values, and ways of operating and expressing their thoughts.

Studies of child perspectives can be described as part of a holistic approach, which covers the relationships between humans, non-humans, objects, and different phenomena. Furthermore, it focuses on children's lives and childhood as comprehensive phenomena through interdisciplinary and cross-disciplinary research by applying multi-method approaches, which may include, for example, ethnography, narration, movements, playing, constructions, photos, and drawings.

Conducting research on children and engaging in activities with them can be justified from a number of viewpoints: the realm of rights, the realm of needs and learning, and the realm of listening, encountering, and sharing. The article explores these realms because they represent important aspects of why we need to observe and apply children's perspectives in research. Children's social participation, which is a multi-faceted phenomenon, forms the central concept for each realm. The article discusses essential elements of children's perspectives and the multiple possibilities offered by the elements for research and working with children. The need to listen to children's perspectives has been emphasised since the U.N. Convention on the Rights of the Child (UNCRC, 1989) was signed worldwide.

This article discusses the Finnish concept 'osallisuus' (in Swedish 'delaktighet'). 'Osallisuus' involves not only participation (in Finnish 'osallistuminen’)
\end{abstract}

(C) LIISA KARLSSON, 2021 | DOI: 10.1163/9789004445666_013

This is an open access chapter distributed under the terms of the CC BY 4.0 License. 
but also acting, involvement, feeling and experiencing, relatedness, belongingness, togetherness, inclusion, and influencing as well as representation, democracy, organising, and governance.

Empirical research will be presented in order to introduce how studies of child perspectives and social participation can more comprehensively reveal different phenomena related to communal and other relationship networks. The empirical data gathered through a focus on child perspectives show that in order to achieve social participation from a child's perspective as a broader concept of a cultural participation, it is crucial to build a reciprocal participatory culture. A reciprocal participatory culture calls for a comprehensive, communal, and systemic understanding of the complexities and relational aspects of time, place, and space, which are in continuous and evolving processes.

\section{Keywords}

children's cultural participation - childhood studies - child perspective UNCRC article 12 - 'osallisuus'

\section{Introduction}

Children and childhood have become a growth area in research and are regarded as interesting and important topics in more and more areas of life. Thus, there has been an increase in studies focusing specifically on children (i.e., persons under the age of 18). Furthermore, there has also been a call to explore in more detail children's actions and the ways in which they communicate, grow, learn, and create their own and shared cultures within a community and in relation to participation (e.g., Farrell, Kagan, \& Tisdall, 2016; Karlsson \& Karimäki, 2012; Corsaro, Honig, \& Qvortrup, 2009).

When studying a child's perspective and social participation, it does not suffice to simply have children produce the research data. The topic should be discussed not only from an adult's point of view but also from that of the children. Therefore, I argue that it is relevant to focus on the concept of participation, which is a central concept both in research and practice (in Finnish 'osallisuus', in Swedish 'delaktighet') from a broader cultural standpoint. When studying children's participation through the lens of children's perspectives, we need to pay special attention to the ways in which the subject, agency, power, and influence are all intertwined. Next, I will discuss the different approaches of child studies, childhood studies, studies of child perspectives, and a child-centered 
viewpoint in order to reflect on the premises of the Finnish concept of reciprocal cultural participation.

Researchers in childhood studies have been engaging in multidisciplinary research in social studies, education, and cultural studies. A key part of these efforts has been the goal shared by different academic disciplines and researchers to understand children in their societies and communities and as agents, as well as to discern how childhood relates to the surrounding society, its structures, and cultures (Alanen, 2009, p. 9; James et al., 1998/1999; Corsaro, Honig, \& Qvortrup, 2009; Corsaro, 2018). As a result, childhood studies and child culture studies have increased and become more diverse.

Depending on the approach, research can highlight very different issues. The essential consideration is not the academic discipline as such, be it cultural studies, education, psychology, sociology, or some other social science, but the theoretical background and the paradigm on which the study is based. As childhood is by nature a multi- and cross-disciplinary phenomenon, a combination of scientific viewpoints provides a more comprehensive outlook on the subject. James and James (2008, p. 25) define childhood studies as an interdisciplinary study of persons under the age of 18 with an active and social child at its center.

We should not overlook the fact that children are experiencing their childhood right now, in real time. They also have their particular manners of being present in the world, acting, learning, and growing, all of which differ from their adult counterparts. Therefore, an orientation of research and action focusing on a child's perspective is needed as well. The aim of this orientation is to uncover children's views and ways of operating and acting. When conducting research or working with children, a concept is needed that describes the child as a subject, a participant, and a data producer, while also including the passive and reluctant sides of children. Figure 13.1 shows the relationships between child studies, childhood studies, and studies of child perspectives in relation to each other and to other cultural, material, and biological contexts.

Data and topical knowledge are relevant to, for example, decision making, education, pedagogy, social sciences, and the cultural sector. Different needs for research data - in other words, who needs information and where contribute to choosing a research paradigm, perspective, and methodology. In studies focusing on children, data and knowledge can be generated by children, parents, or experts. Involving children in the process of producing data allows them to likewise participate in the research as well as in the practical 


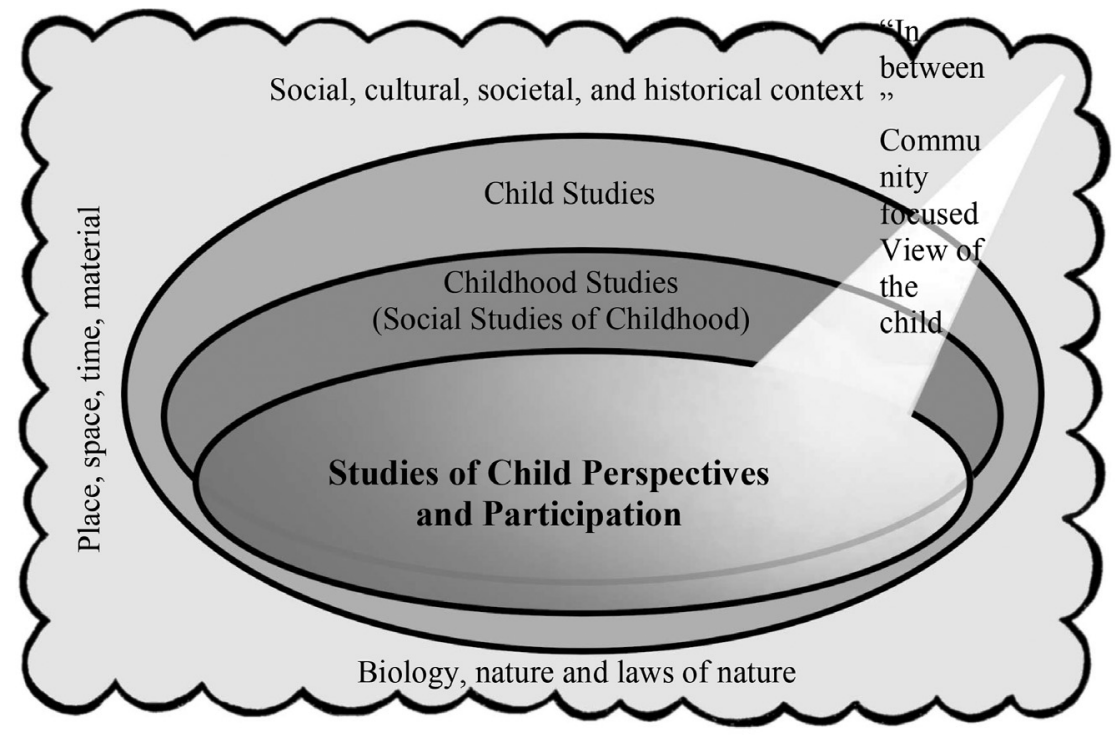

FIGURE 13.1 Child studies, childhood studies, studies of child perspectives, the child-centered view, and social participation in different contexts

phases of the study. Several methods are typically employed when gathering data on children, and they can be divided into five categories (Karlsson, 2012a): 1. Data may be gathered from children in real time by recording, filming, photographing, or observing children and the adults around them, or by utilising applications such as smartphones.

2. Both children and adults can produce data in retrospect by answering questionnaires, participating in interviews, reminiscing, and expressing their thoughts verbally or in writing, or by using symbols, emojis, pictures, or body language.

3. Valuable data can also be obtained from children's works, for example stories, writings, journals, presentations, recordings, constructions and crafts, photos, videos, movements, maps, and drawings. The material can be produced as part of normal daily activities or specifically for research purposes. Adults' works can also depict their own childhoods or the children with whom they interact.

4. Research materials can include documents, such as statistics, procedural texts, laws, regulations, political programs, and historical documents. These materials are created by adults.

5. One type of data consists of public information, including information presented by the media, social media content, and forum discussions, which are mainly produced by adults. 
Even in studies on children, adults still produce most of the data. Another potential issue is that studies focus on a single phenomenon and therefore do not provide an overall picture of childhood.

\section{3} The Essential Elements in Studies of Child Perspectives

The aim of the studies of child perspectives is to examine children's and youth's (persons under 18) views, the data they produce, and their social participation (Karlsson, 2010, 2012a, 2013). This leads to listening to children's signals and information in various ways and to analysing children's experiences and views, their actions and values, and their ways of operating and expressing their thoughts. Children should not be romanticised or isolated from other age groups, although the special traits of childhood should be taken into account. Moreover, children should not be viewed as a uniform group; rather, different childhoods and viewpoints should be observed. Furthermore, children's points of view and words are best viewed in relation to other perspectives, which can be those of adults, communities, or animals and which may originate as a shared outcome between different elements, such as space, expectations, matter, biology, or habits of action (Karlsson, 2012a, 2013).

An empirical example provided in one study (Hohti \& Karlsson, 2013) clearly shows how the phenomenon in question appears differently when the child perspective is applied. During fieldwork, the researchers focused on a single school day from different perspectives. On that particular day, the class was preparing for their spring festival. The researchers found that the discursive frame of the festival allowed children only a narrow space for their actions and voices. Children were supposed to stand still and they could use their voices only for singing, but even then, they had to use their voices carefully. Those children who behaved well in the rehearsal were given lollipops. The researchers wanted to use the Storycrafting Method, a participatory method to listen to children's perspectives; the children were able to tell a story about anything they wanted to because the aim of the method is to give the child freedom and space to tell their own story (Karlsson, 2013). Surprisingly, the stories that the children told were about the festival rehearsal and the control they had experienced:

The title of Jani's story:

Jani, who didn't like Matias because he ate lollipops all the time, which Jani didn't like. Once upon a time, there was Jani, who didn't like lollipops. Or the lollipops that Matias is munching next to me. The end. 
This empirical example from the research data shows that the phenomenon being researched, as well as our understanding of social participation, becomes more comprehensive and multi-dimensional when applying a child's perspective; in this example, the researcher took the position of the listener and had the physical space and time to listen to the children's voices. Without the participatory space, the children's voices would not have been heard.

The study of child perspectives focuses on a holistic approach (Karlsson, 2010, 2012a). There is always the question of what happens 'in between' in the relationships between humans, non-humans (Prout, 2005), objects, and various phenomena. Disciplines should not limit the subject being studied nor its analysis; instead, the focus should be on children's lives and childhood as comprehensive phenomena on cultural participation. Thus, this field of research is interdisciplinary and cross-disciplinary by nature (see Mikkeli \& Pakkasvirta, 2007). Nothing occurs on its own or in a vacuum, but rather in relation to other issues, as self-expression and its various forms and types of content are linked to the cultures, subcultures, and environments in which people operate as well as to social, societal, historical, material, and biological contexts. Consequently, the studies of child perspectives also investigate children's interactions with adults and others as well as broad contexts in different macro and micro cultures. This means that research on child perspective is community-focused, implying that researchers should not just adopt concepts that highlight children, such as child-focused studies or child-centered studies (Karlsson, 2012a). The studies of child perspectives overlap with other research orientations, such as research on minorities and marginalisation.

Researchers have started to employ methods that encourage subjects to participate more in the study and have developed multi-method approaches that utilise, for example, ethnography, photos, and narration (Honkanen et al., 2018; Kinnunen \& Einarsdóttir, 2017), as well as the mosaic approach (Clark \& Moss, 2011). Children are included as co-researchers in a variety of modes of action (e.g., Kjær, 2015; Hakomäki, 2013; Lundy, Mcevoy, \& Byrne, 2011; Clark \& Moss, 2011; Karlsson, 2014, 2005; Tisdall et al., 2009; Christensen \& Prout, 2000; Jørgensen \& Kampmann, 2000; Alderson, 2000). Here, children are considered active producers of data and knowledge instead of research subjects. Especially in the 21st century, children have been included in the research process as active participants (see also Sommer et al., 2010). They take part in ways that come naturally to them, such as playing (e.g., Cederborg, 2020; Vuorisalo, Rutanen, \& Raittila, 2015; Rainio, 2010), talking and telling stories (e.g., Engel, 2006; Karlsson, 2013; Weckström et al., in press), and taking photos (e.g., Honkanen et al., in press). Children can study a variety of phenomena (e.g., Weckström et al., in press; Stenvall, 20o9; Raittila, 2008). In some cases, children have 
been encouraged to form their own research questions, which they then try to answer through research, and their research question has also been included in the scope of the actual scientific study (e.g., Hakomäki, 2013; Hakomäki \& Karlsson, in press; Tuovila, 2003). Researchers may also present their findings to the children before the study results are published (e.g., Hohti, 2016). Hence, we could argue that this discipline is currently undergoing a paradigm shift (e.g., Fargas-Malet, 2010; Karlsson, 2012a, 2013).

The child perspective affects the whole research process: forming the research task and questions, producing the data, choosing the methodology, conducting the analysis, drawing conclusions based on the findings, and publishing the results (Karlsson, 2012a). However, researchers can never truly experience what life is like for those who participate in the study or get inside the participants' heads. This naturally applies to all research (Karlsson, 2012a). In short, the studies of child perspectives highlight issues discussed by children or arising from children, while placing the complexity of these phenomena in a broader context.

James and James (2008, p. 19) suggest that child-focused or child-centered research is the core element of childhood studies. Children are seen as subjects and actors rather than as the objects of research (James \& James, 2008, p. 17). Children are not merely actors with something to say. They have views that they are capable of presenting in a research-oriented context (Jones \& James, 2008, p. 17). The "studies of child perspectives" approach includes the concept of "children's perspectives", which "represent children's experiences, perceptions, and understanding in their life-world" (Sommer et al., 2010; see also Lewis \& Lindsay, 2000).

With the studies of child perspectives, information provided by children forms the basis of child-perspective activities. This information is paired with expert knowledge and skills through activities, which are communal and reciprocal. The orientation of actions comprises inquiry, experimentation, and wonder: both the children and the professionals pose questions and try to answer them on their own. Even though children's perspectives are considered, it will not result in excluding or belittling the capabilities and actions of adults. On the contrary, it is essential to observe everyone's perspectives and the community as a whole. When working with a focus on children's perspectives, these overall ideas form the basis for research activities.

It could be argued that there is no need for a separate 'child perspective', and instead we could focus on the perspectives of all actors, agents, and communities. The risk then lies in children's perspectives being overshadowed by stronger and more forcefully presented points of view, which is hardly a novel 
outcome. Adults' positions of power, practiced writing skills and verbal skills, wealth of experience, and specialist knowledge can easily take over and dominate. For example, there is a trend of engaging in problem-centric discussion, where the focus is placed on children's shortcomings, hardships, and points of development. In reality, children are similar to adults, as well as special and different from them. Studies and activities with a child perspective pay attention to all sorts of signals from children, which means that children's strengths and skills are also observed as opposed to only their weaknesses and troubles. Furthermore, the manner in which children act, express themselves, and deal with issues differs from how adults operate. This calls for special attention. Table 13.1 presents some visible differences between the currently predominant child research approach and the studies of child perspectives.

TABLE 13.1 Differences between the currently predominant child research approach and the studies of child perspectives

Predominant approach

The approach of the studies of child perspectives

Adults define and produce information and knowledge. Research focuses on the views of teachers, experts, and parents on matters affecting children.

Discussions revolve around adultcentric definitions and often negative phenomena and indicators (e.g., incapability, health problems, impairments in interaction, learning disabilities).

Adult perspective Phenomena are often examined from one discipline's point of view and using one method.
Children and youth produce information and knowledge (together with adults). Since the research focuses on children, issues are studied together with children. In addition to problems, positive, constructive, and joy-inducing elements of children's and youth's lives, perspectives, and experiences are observed.

\section{Child and community perspective}

Answers (to a holistic and systemic, multifaceted whole) are sought utilizing a multidisciplinary and often multimethod approach.

Research on children and engaging in activities with them can be justified from a number of perspectives. The next section expands on some points that can be used as arguments for why we need to observe and apply a child's 
perspective. Research and activities with children can be seen as different realms: the realm of rights, the realm of needs and learning, and the realm of listening, encountering, and sharing. In these realms, children's social participation is the central concept, which is a multi-faceted phenomenon.

Children's (persons under the age of 18) rights in society are globally defined by the United Nations Convention on the Rights of the Child (UNCRC, 1989), which all UN member countries have ratified except for the U.S. The convention includes all the key principles of the Declaration of the Rights of the Child (1959). It is a legally binding document, and it has greatly affected national laws. Some noteworthy examples include the Finnish constitution (Section 6, 1999/731), inter-branch laws, political agendas, and curricula.

Article 12 of the UNCRC (1989) asserts:

States Parties shall assure to the child who is capable of forming his or her own views the right to express those views freely in all matters affecting the child, the views of the child being given due weight in accordance with the age and maturity of the child.

It stands to reason that children shall also have a say in matters affecting them in studies of children and activities with them. The need to consider the views of children based on their age, capabilities, and stage of development should not be taken to mean that young children or children with disabilities are unable to make an impact. Instead, the inclusion of age and stage of development into the equation challenges researchers, professionals working with children, and others to look at issues from a child's perspective. We should aim to develop the ways of operating that come naturally to children. There are several ways to include children in studies and listen to their voices. Next, I will discuss how the rights of the child are put into effect and what matters demand particular attention.

When children are considered in line with the UNCRC, we are operating in the realm of rights. Children as a group can be observed in several other realms, such as the romantic, advocacy, needs, learning, institutional, and proactive realms (Francis \& Lorenzo, 2002, p. 164). Furthermore, children can be discussed within the realm of listening, encountering, and sharing (Karlsson, 2012a; see also Rainio, 2010). The next sections concentrate on several of those realms. 


\subsection{Realm of Needs and Learning}

In the realm of needs and learning children can be observed from the standpoint of a child's level of self-determination and motivation (see Isola et al., 2017). Ryan and Deci's (2000, 2017) theory of self-determination examines people as actors striving to achieve goals that they have personally set. The theory suggests that people have three basic psychological needs: autonomy, showing competence, and relatedness. The theory has been developed, studied, and expanded since the 1970s. For example, the theory has recently received a fourth dimension: benevolence (Martela \& Ryan, 2015). According to self-determination theory, motivation is a result of satisfying basic needs. When autonomy is promoted by listening to subjects and providing them with options, studies have found, for example, the onset of more beneficial exercise behavior (Hynynen \& Hankonen, 2015, p. 483). When subjects have been presented with an opportunity to show benevolence, they have felt a sense of purpose, appreciation, and dignity.

Another point of view has been offered by Bandura (1977), who discusses the concept of self-efficacy as entailing a person's trust in their own abilities in a certain situation. People with a strong sense of self-efficacy tend to accept more challenging tasks and achieve goals more efficiently than others (e.g., Kavanagh \& Bower, 1985). Research indicates that students with higher selfefficacy display more effort and perseverance, for example when engaged in demanding writing tasks (Schunk, 2003). Self-determination, motivation, and self-efficacy are important phenomena that create space for children to act and present their views. The studies of child perspectives provide this space, and thus, participating in the study often inspires and motivates children and supports their possibilities to improve self-determination and self-efficacy. However, in order to create a more holistic perspective, I will next discuss in detail the child's whole community and its dynamic operational environment.

\subsection{Subjectivity, Agency, Community, Social Participation, and Power- Towards the Realm of Listening, Sharing, and Encountering}

When children are viewed as part of a community and an operational environment, the following concepts arise: the states of subject (subjectivity) and object, agency and sense of community, social participation and nonparticipation, and the power involved in providing room for the subject state and participation, or in limiting them. What do these concepts mean in practice, though?

As mentioned earlier, a child is not an independent or isolated actor. When a child is born, he/she grows, learns, and undergoes changes within a certain social, cultural, and material environment and exists in a constant state of 
interaction. Both children and adults can simultaneously be considered beings or persons acting in the moment and becomings, or subjects-in-process (Lee, 20o1; Prout, 2005; Kennedy, 2006; Rainio, 2010). They are both strong, fragile, and active agents and in need of protection, and they are capable as well as learners. The states of subject, agency, participation, or power do not define an individual as an absolute, nor are they measurable and static features. Instead, these concepts should be regarded as dynamic phenomena: they are everchanging, connected to people and various matters, and contextual. The phenomena and the concepts that represent them are overlapping and connected, network-like relations. They are born in context-specific interactions in communities and spaces. Hence, subjectivity, agency, participation, and power are dynamic, communal, and relational concepts (e.g., Prout, 2005). Power and the states of subject or agency cannot simply be taken for granted; rather, they reflect a constantly changing relationship with others. In some situations, agency is easily accessed and allowed to surface, but in others it is not available, or the person does not want to strive for a position of agency. On the other hand, self-exclusion and opposition are expressions of agency and power.

Any situation can involve various areas of power and agency. For example, it may prove to be less difficult to utilise power when facing a peer than to exercise that power over an adult who is in charge of an activity. Each actor's visible or implicit actions, or intentions, have an impact on others and are simultaneously affected by others' actions. Predominantly, several conscious and unconscious actions occur at the same time. Therefore, actions or events are not linear in relation to each other; rather, they are intertwined like a net and partially entangled. Power is a social resource, as well as a network of sociocultural interpretations and communication (see also Thomson, 2007), but it involves other factors as well, such as the operational environment and material and biological bases (see also Barad, 2007). The world is comprised of entanglements of both 'social' and 'natural' agencies, and nature and culture interact and change over time (Barad, 2007).

In summary, the concepts of subjectivity, agency, community, participation, and power always exist in connection with the observed phenomenon and with time, place, and space. Subjectivity, agency, community, participation, and power are not individual, static features. Instead, these phenomena emerge among human beings, in dialogue, through listening to each other, encountering one another, and sharing together. Consequently, subjectivity, agency, community, participation, and power help to create a realm of listening, encountering, and sharing. 
In this section, I will examine social participation in more detail. Social participation allows us to discuss essential parts of the child perspective and its chances of being realised in research and in working with children. I shall also discuss what additions the child perspective can bring to defining and realising participation as a broader cultural phenomenon.

There are multiple definitions for the phenomenon and concept of social participation and involvement. In a broad sense, participation can be characterised by three dimensions: having, acting, and belonging (Raivio \& Karjalainen, 2013; Allardt, 1976; Isola et al., 2017). The last two could be included in the social participation of children, which entails mechanisms for people to participate in making social decisions.

Children's social participation, and especially the Finnish concept of 'osallisuus' (in Swedish 'delaktighet'), is a multifaceted phenomenon. The concept involves participation, acting, involvement, feeling and experiencing, relatedness, belonginess, togetherness, inclusion, influencing and representation, democracy, organising, and governance (see also Isola et al., 2017; Kangas, 2016; Karlsson, 2012a; Weckström et al., in press). Social participation consists of an entangled union of the states of subject, agency, power, and influence. When a child is treated as a subject or actor with meaningful thoughts and views, the child has an opportunity to enter the position of an active participant within the community. Whoever organises an activity also possesses the power to affect whether space and opportunities are presented for others to achieve the states of subject, agency, and participation. Then again, the child may or may not accept the role of active agent. Additionally, numerous factors influence participation and agency, such as other children and adults, experiences, expectations, an operational culture or community culture, space, objects, biology, and other phenomena, as well as the relationships and tensions between all of these elements.

The key to social participation is giving the child an opportunity to participate and to have an effect as well as allowing the child to feel involved and included. Social participation manifests itself as mutual respect, equality, and trust within a community. Taking part and having influence are gateways to social participation. The concept of social participation has been specified according to different dimensions and levels. Shier (2001, p. 110; see also Hart, 1995) has introduced five levels of participation: (1) children are listened to, (2) children are supported in expressing their views, (3) children's views are taken 
into account, (4) children are involved in decision-making processes, and (5) children share power and responsibility for decision making.

These levels of social participation resurface in a new light if they are examined from a qualitative perspective and from the perspective of power and decision making. This highlights not only what action is taken, but even more what kinds of issues these actions address, who makes decisions regarding the actions, and on what grounds. In other words, from the qualitative perspective the essence of the first level of social participation inquires as to whose views are listened to and what criteria are used in deciding what is worth listening to. On the second level, we should ask what types of expressions and content are allowed in children's self-expression, what types are not acceptable, and why. The third-level's qualitative questions include, for example, which of the children's ideas are taken into consideration, by whom, and how. The fourth level of qualitative questions asks what activities the children can affect, are they allowed to have an influence on crucial and important actions, and who decides what is considered a crucial and important action. The method of determining what is important to the children also has a significant role in shaping this level. On the fifth level, attention should be given especially to how and by whom decisions are made in situations where children are also responsible for the outcomes, what the decision-making process involves, on whose initiative the decisions are made, how and by whom the decisions are arrived at, and how these decisions are addressed.

The requirements for social participation of children have noteworthy counteractions and downsides. Active and participating children may become a norm, which isolates children from each other (see Prout, 2003, p. 22). Discussions of agency and social participation can place a heavy focus on an individualistic point of view. If children's activity is highlighted as a trait, it may distort or blur the meaning of the boundaries in the community and culture, the historical and biological factors, and political and financial structures. Children should not have limitless opportunities for agency, and action should not be a venture of omnipotent individuality. The rise of individualism (e.g., Koskelainen, 2017) is present in criticisms of child-focused activity (Hytönen, 2008). The social effects of one person's actions on others may become difficult to detect. The current life of any person is a result of the person's, community's, and society's history. Goals and boundaries for any action are based on current structures and cultural norms. When attention and focus are placed on actively pursued actions, they simultaneously marginalise the silent, passive, and invisible (e.g., Gordon et al., 2002; Rainio, 2010). The studies of child perspectives and childhood studies face the challenge of combining micro- and 
macro-level perspectives with a discursive, evolving, and societally influential research genre.

\section{The Key to Children's Social Participation Can Be Found in a Reciprocal Participatory Culture}

How does adopting a child's perspective affect our ideas of social participation? Does a child's perspective inspire new understanding or revelations? First, I introduce and define the concept of reciprocal participatory culture. With a reciprocal participatory culture, all participants - children and adults of different ages - have an opportunity to be heard and appreciated. Everyone can take initiative and affect the decision-making process, regardless of their age, skills, or backgrounds. Thus, the different ways in which participants take action are respected. A reciprocal participatory culture involves a shared understanding of 'we' rather than 'us and them'. Reciprocal participatory culture calls for a comprehensive, communal, and systemic understanding of the complexities and relational aspects of time, space, and place, but also of relations with the biological bases and material aspects of the phenomena of power. This understanding is shared and invoked in continuous and evolving processes as part of a broader continuum or process and not as a set of individual actions. Reciprocal participatory culture involves the creation of a (transparent) system, certain attitudes, views, spaces, and actions, which are justified and agreed upon together as a community.

From an adult's perspective, in a reciprocal participatory culture both adults (e.g., researchers, teachers, parents) and other children see a child as an interesting person who shows initiative and has her/his own ideas, knowledge, views, and ways of acting, all of which are worthy of examination. Adults give children an opportunity to have an influence on their daily activities. In a reciprocal participatory culture, the adults are also active subjects and participants. Social participation can be regarded as a shared process between children and those who are acting with them. The process affects both the individual and the community. In a reciprocal participatory culture, adults cannot fully plan ahead or know the outcomes of particular actions. The views of children and the expectations and intentions of adults set the boundaries or provide the opportunities for children's actions and a framework for how children see their position and chances for acting in relation to that of others. The focus lies in achieving a clear sense of the activities and shared goals involved. Additionally, interaction, place, space, material, and biological factors affect the larger whole. A reciprocal participatory culture requires mutual 
understanding and that the participants take steps to build a reciprocal participatory culture through practical actions. This shared process helps create a better understanding of the concept involved.

When we take a closer look at the levels of children's social participation and their qualitative aspects, it becomes apparent that they are based on an adult's perspective. Social participation is in fact defined through adults' actions. When a child's perspective is introduced into the equation, the phenomenon can be observed more comprehensively, through communal and other relationship networks. This approach uncovers new issues and provides new focal points. Our understanding of social participation becomes more thorough, and some parts of it may change notably. This could either become a sixth level of social participation or rather a new, more comprehensive, qualitative, dynamic, and emerging way of dissecting social participation.

Here, I would like to highlight the empirical research example from a prior study (Hohti \& Karlsson, 2013) already presented in this paper because it shows that children's social participation is not unitary and complete, but rather emergent and contingent upon the discursive, social, material, and physical resources available. Hohti and Karlsson's (2013) study tracked the voices of the children through three different discursive spaces. They discovered that the observational space, which was constructed by observing the class rehearse for a spring festival, illustrated a struggle between the controlling institutional voices of the teacher and the voices of the children. Children's voices appeared to be mostly defined by the teacher as largely irrelevant, disturbing, and as signs of behavioural problems. Hohti and Karlsson (2013) additionally found that the participatory space was created via a participatory narrative method, Storycrafting (Karlsson, 2013, 2014). With the method, children were given an opportunity after the rehearsal to tell any story they wanted to the researcher (Hohti \& Karlsson, 2013). In this space, it became possible to hear the children's voices in (the physical and) the discursive senses, and children's narratives were positioned as knowledge. The stories - the narrative voices of children - provided diverse and surprising perspectives on classroom interactions. The analysis revealed children's performative styles of elaborating on the power relations they had experienced, in which reciprocity, friendship, and humor were crucial. The researchers were now able to see how the children talked about the rehearsal situation and their individual ways of coping with that situation. The participatory method allowed children to construct meanings, which was not the case before.

The reflexive space of listening was entered when the researchers started to question their own ways of selecting and interpreting children's voices (Hohti \& Karlsson, 2013). After focusing on the discursive, social, and physical 
dimensions of the narratives, attention was turned to listening to voices, and more stories that had been left out of the study at an earlier stage were analysed. The reflexive space showed that by listening to the easier-to-understand voices, a gendered and simplified picture of children's worlds was realised. Through reflexive listening, it was possible to embrace children's diversity and to bring to the center the cultural and collaborative dimensions of children's narrative activity.

This empirical example of the holistic and reflexive approach shows that in order to promote social participation, adults must take responsibility for creating spaces for children's voices. Hence, time is needed for reflexive listening through repeated considerations and experimentation on the researchers' part. Furthermore, entering the reflexive spaces of telling and listening can also help intervene in the persistent controlling practices in schools and early childhood education and to build spaces for the complex and diverse voices of children.

When social participation is understood as an emotion arising from the experience of communal inclusion, it cannot be considered a specific action taken at a given moment, after which a new way of acting is adopted. Actions seem contradictory and confusing from a child's perspective if in one moment the child is expected to show initiative and present ideas, while similar active participation becomes a distraction during the next task. In order to achieve social participation from the child's perspective, participation must be viewed as part of a broader continuum or process and not as a set of single actions. This, in turn, is a fundamental shift in a reciprocal participatory culture. Here, reciprocal and social participation is present in subtle actions, word choices, and objects, as well as in lengthier processes, larger environments, and principles guiding people's actions. The attitudes of the adults in charge are a decisive factor (e.g. Olli et al., 2012). Adults' views about children in general and about the children with whom they interact are essential. The views, expectations, and intentions of adults set boundaries for children's actions and provide a framework for how children see their position and chances for acting in relation to that of others.

As discussed earlier, social participation is often observed from an individual's perspective instead of focusing on the point of view of a community. People operate within a community, and there can be no social participation without community-level activity. When we observe social participation from a child's perspective, shared activities and spending time with others become important matters. Virkki's (2015) research indicates that educators emphasise individualistic elements, but children place more value on community or group activities. For children of all ages, friends as well as family 
members are extremely valuable (e.g., Hayball et al., 2018; Honkanen et al., in press). Children's participatory actions correlate positively with peer relations, play, and positive emotions (Arvola, Lastikka, \& Reunamo, 2017). School children who are popular with their peers offer more positive evaluations of their own behavioral and emotional strengths than children who are rejected by their peers (Rytioja et al., 2019). Friendships and a sense of belonging are even connected to learning. According to research, children who enjoy positive relationships with their peopers experience more emotional well-being, have a greater sense of self-worth, and excel at academic tasks compared to those without positive peer relationships (Wentzel, Donlan, \& Morrison, 2012, p. 79). Research (Rytioja et al., 2019) shows that children in the 'popular' status group perform better academically and report less emotional distress in their self-evaluations than others.

A child's perspective challenges scholars to delve deeper into the less researched community perspective. This involves shared activity, interaction, and relationships where both human and non-human participation in social life is addressed (Prout, 2005).

\section{7 \\ The Studies of Child Perspectives Open New Avenues}

The studies of child perspectives have revealed new ways of looking at several phenomena. When researchers studied residential areas from a child's point of view, children were able to introduce many issues relevant to developing residential areas and services for families (Honkanen et al., 2018). To a child, place and space are linked. The concepts of place and space are defined differently. In humanistic geography, the understanding of place has recently been changing. The place can be seen as both a socially produced and personally experienced space (Hyvärinen, 2014; see also Campbell, 2018). However Duhn (2012) defines place as a recognizable, physically built, or natural place. But for humans, lived places constitute not only a physical environment. A place has different meanings when it is connected with emotions, actions, and memories. Here, the starting point is that space is relationally produced through everyday actions and interactions in a process that is intertwined with physical environments and places and concrete objects, personal interpretations of physical and cultural space, and cultural and collective views (Vuorisalo et al., 2015; Soja, 1996; Bourdieu, 200o; also Zhou et al., 2019). Space is not a neutral context or background for action, but involves collective definitions and ideas (Vuorisalo et al., 2015).

According to a recent study (Honkanen et al., in press), a place becomes meaningful to children when it serves as a location for activities with friends, 
or when children can feel safe and experience a feeling of togetherness with other people, like parents or siblings. The researchers identified two essential types of places where children experience a sense of well-being: open public places where children meet up with friends (e.g., day-care centers, schools, playgrounds, family parks, shopping malls, youth centers) and bordered private places where children feel safe (e.g., home, the yard, a grandparent's home, 'secret places') (Honkanen et al., in press).

Children can also help determine how different methods, such as the Storycrafting or Storycomposing, work. In one experiment (Hakomäki, 2012, 2013), a young researcher together with a Ph.D. assistant, and music therapist used the Storycomposing method as well as the co-researcher's past experience with music therapy to create a place for children to tell their own stories. Storycrafting allows researchers to hear the thoughts of children and adults of different ages, get to know them, and build a reciprocal participatory culture for the community (Karlsson, 2013; Karlsson et al., 2018). Children also use the Storycrafting method to engage with power structures. Piipponen and Karlsson (2019) found that children participate in an intercultural Storycrafting exchange by narrating stories in a complex cultural web of connections, one which included their classmates, their teacher, and the partner class in another country. Story exchange promoted reciprocal intercultural encounters within and between the two groups of children, where the children find a way to connect as equals. Thus, the Storycrafting method creates a qualitatively deeper and reciprocal means for cultural exchange. The story exchange between the two classes was not only intercultural; important intracultural encounters occurred within the groups as well.

Research in nursing science (Olli et al., 2012, 2014) has shown that a child's perspective is rarely acknowledged in traditional, professional-centered nursing care or habilitation nursing, which emphasises vulnerability, and in the medical model of disability. These nursing functions and the procedures they generate are based on an adult's, and more specifically on a professional's, perspective. According to one study (Olli et al., 2014), the lack of consideration for a child's perspective is seldom recognised by healthcare professionals, because nurses feel that they are working with the child's best interest at heart. Nurses already treat children with kindness and give them opportunities to express themselves, for example by choosing their own toys or what they want to drink. When a habilitation program is developed, no consideration is apparently given to how matters seem from a child's perspective or the underlying thought patterns guiding the procedures. Olli et al. (2012) found that the lack of consideration for a child's perspective is also seldom recognised by other professionals, for instance teachers in early childhood education and school, educators at different levels, or social workers. 
Several studies of child perspectives take an ontological post-humanist approach, highlighting how important it is to note the relationships and entanglements between multiple entities. Children and childhood are part of larger relational situations. The human, non-human, material, and place are all intertwined. Findings presented by Rautio, Hohti, Leinonen, and Tammi (2017) tell us how inseparable childhood is from place, and how they form side by side. The complexity of childhood and the concept of multispecies childhood is discussed by Hohti and Tammi (2019). Schooling, pedagogy, social participation, and childhood are redefined when the relational scope is expanded beyond human relationships in the studies of child perspectives (Tammi, 2019, 2020). Children may hold in high value mundane, material, funny, and contradictory objects, such as the pages of a book, seats, football cards, pens, jokes, animals, and children's stories, all of which have an impact on children's existence and learning, even though they have not always been taken into consideration in educational research (Hohti, 2016). For children, such institutions as schools or early childhood education settings are an inseparable aspect of their lives. For example, most Finnish school children own a smartphone, and the phones connect children's daily lives and school by becoming entangled in a web of things, bodies, emotions, time, and space (Hohti, Paakkari, \& Stenberg, 2019).

\section{Conclusions: Communal, Collaborative and Shared Social Participation in a Reciprocal Participatory Culture}

Finally, I will connect the child perspective to a reciprocal participatory culture. In this reciprocal participatory culture, adults see children as interesting persons who show initiative and have ideas, knowledge, views, and specific ways of acting that are considered worthy of examination. In this context, children have an influence on daily activities (see also Turja, 2016; Kangas, 2016; Kangas \& Lastikka, 2019; Weckström et al., 2017).

The supervising adult's views of an active child have an impact on the ideas and actions of the whole community. In a reciprocal participatory culture everyone can show initiative and affect decision making, regardless of their age and skills (Karlsson, 2012a, 2013; Riihelä, 200o). Initiatives can mean suggestions, ideas, and questions, but they can also simply be expressions conveyed through body language or actions, such as playing, acting silly, or excluding oneself from a shared activity. In fact, adults need to be particularly alert and sensitive to these kinds of initiatives and expressions. Above all, they should be able to register the subtlest of signals during activities, their planning, and their realisation. It is also a matter of adults' communication skills (Olli et al., 2012): 
how adept are they as listeners, and can they communicate without words, for example by playing or utilising humor or through observation and recognition? The person in charge of an activity, who is usually an adult, has power and influence. It is the adult's responsibility to ensure that he/she sees, hears, and understands even the most laconic initiative or signal and that those messages are included in activity planning. It is also important to develop ways of acting that promote children's initiatives.

In a reciprocal participatory culture, the adults are also active subjects and participants. Social participation can be regarded as a shared process between children and those who work with them, and the process affects both the individual and the community (e.g., Hart, 1992; Kiili, 2006; Venninen \& Leinonen, 2013), as well as time, space, place, and material. Research suggests that a group of children struggles with social participation if the workers in the group do not experience social participation as well (Karlsson, Weckström, \& Lastikka, 2018). Parents' active social participation has also proven to be a crucial factor. According to a number of studies, parents' active social participation is connected to their children's academic success (e.g., Díez, Gatt, \& Racionero, 2011; Gatt, Ojala, \& Soler, 2011; Epstein, 2009). Also, parents' sense of academic efficacy and aspirations for their children are linked to their children's academic achievement. In turn, children's beliefs in their efficacy to regulate their own learning and academic attainments contributed to scholastic achievement (Bandura et al., 1996).

A reciprocal participatory culture involves taking a critical stance towards 'the other' and towards classifying a person as the other (Hummelstedt-Djedou et al., 2018). A child should not be considered 'the other', a person who needs to swiftly adjust to adult norms. In this way, children and families avoid viewing employees as the other, or as someone who should be opposed or pleased. Furthermore, parents should not be considered, for example, customers who require special treatment. Instead, all actors should be viewed as members of 'our community', where people share the same main goals. Each individual should still be respected and valued as a unique person and exactly as he/she is. However, a single father, a Nigerian mother, a special education teacher, or a disabled child does not represent being 'special'. They should primarily be viewed as individuals with different goals, ideas, dreams, ways of acting, and skills, who are valued members within the same community. Everyone should receive the same treatment as an interesting subject and actor. Alongside human contact, children have been found to hold animals in high value as subjects and co-actors (Hohti \& Tammi, 2020; Karlsson, 2012b). Considering the abovementioned findings, a sense of community and individualism are closely connected. 
In a reciprocal participatory culture, adults cannot fully plan or know the outcomes of their actions. When making plans, the focus lies instead on achieving a clear sense of the activities and goals involved, and therefore, planning should emphasise how, where, and with what equipment activities should begin and seek procedures where children have the opportunity to reflect, do, and create as much as possible. Additionally, interaction, place, space, material, and biological factors affect the larger whole.

Social participation should not be promoted only 'from above'. Instead, social participation involves the whole community and is often active by nature, but it can also simply be a sense of belonging. Social participation is not a constant or static state of being, and various degrees of participation can be observed in different situations. Still, from a community and child perspective, social participation is a starting point and always present in some form. An active effort should be made to allow children room to participate in activities wherever they may take place.

When we examine social participation from a child's perspective, we discover that in order to achieve participation, one must foster a reciprocal participatory culture in which a comprehensive, communal, and systemic understanding of the complexities and relational aspects of time, place, and space as continuous and evolving processes exists. Then, social participation involves the creation of a (transparent) system, certain attitudes, views, spaces, and actions that are justified and agreed upon together as a group. This, of course, does not suggest that a reciprocal participatory culture should be completed and achieved at once. Once a mutual understanding has been reached, people can start taking steps to building a reciprocal participatory culture. Taking practical action helps participants to better understand the concepts involved, and as a result, the next step can prove to be more profound than its predecessor. This should be considered an adventure; it is a matter of seeking, finding, questioning, failing, wondering, enjoying, delving deeper into the work, and laughing.

The 1989 UNCRC has had a crucial effect on our understanding of children and the studies of child perspectives. Listening to children's perspectives has been emphasised and will continue to be emphasised even more in the future.

\section{Acknowledgements}

Heartfelt thanks to the 'Child perspective' research group: Otto Burman, Hanna Hakomäki, Timo Hirvonen, Riikka Hohti, Kati Honkanen, Satu Vasenius, AnnaLeena Lastikka, Johanna Olli, Antonina Peltola, Oona Piipponen, Noora Räihä, 
Tuula Stenius, Tuure Tammi, and Elina Weckström. They provided and discussed novel, emerging, revealing, and thought-provoking points of view. The warmest thanks to Oona Piipponen and Anna-Leena Lastikka for their help.

\section{References}

Alanen, L. (2009). Johdatus lapsuudentutkimukseen. In L. Alanen \& K. Karila (Eds.), Lapsuus, lapsuuden instituutiot ja lasten toiminta (pp. 9-30). Vastapaino.

Alderson, P. (2000). Children as researchers: The effects of participation rights on research methodology. In P. Christensen \& A. James (Eds.), Research with children: Perspectives and practices (pp. 241-257). Routledge Falmer.

Allardt, E. (1993). Having, loving, being: An alternative to the Swedish model of welfare research. In M. Nussbaum \& A. Sen (Eds.), The quality of life (pp. 88-95). Oxford University Press.

Arvola, O., Lastikka, A.-L., \& Reunamo, J. (2017). Increasing immigrant children's participation in the Finnish early childhood education context. The European Journal of Social and Behavioural Sciences (EJSBS), 20(3), 2538-2548. http://dx.doi.org/ 10.15405/ejsbs.223

Bandura, A. (1977). Self-efficacy: Toward a unifying theory of behavioral change. Psychological Review, 84(2), 191-215. doi:10.1037/0033-295x.84.2.191 PMID 847061.

Bandura, A., Barbaranelli, C., Caprara, G. V., \& Pastorelli, C. (1996). Multifaceted impact of self-efficacy beliefs on academic functioning. Child Development, 67(3), 12061222. doi:10.1111/j.1467-8624.1996.tbo1791.x

Barad, K. (2007). Meeting the universe halfway: Quantum physics and the entanglement of matter and meaning. Duke University Press.

Bourdieu, P. (2000). Pascalian meditations. Stanford University Press.

Campbell, C. J. (2018). Space, place and scale: Human geography and spatial history in past and present. Past and Present, 239(1), e23-e45. doi:10.1093/pastj/gtwoo6

Cederborg, A. (2020). Young children's play: A matter of advanced strategies among peers. Early Child Development and Care, 19o(5), 778-790. doi:10.1080/ o3004430.2018.1491561

Christensen, P., \& Prout, A. (2002). Working with ethical symmetry in social research with children. Childhood, 9(4), 477-497.

Clark, A., \& Moss, P. (2011). Listening to young children: The mosaic approach (2nd ed.). National Children's Bureau.

Corsaro, W. A. (2018). The sociology of childhood (5th ed.). Sage Publications, Inc.

Corsaro, W. A., Honig, M., \& Qvortrup, J. (2009). The Palgrave handbook of childhood studies. Palgrave Macmillan. 
Deci, E. L., \& Ryan, R. M. (200o). The "what" and "why" of goal pursuits: Human needs and the self-determination of behavior. Psychological Inquiry, 11(4), 227-268. Retrieved January 4, 2019, from https://users.ugent.be/ wbeyers/scripties2012/ artikels/The-what-and-why-of-goal-pursuits.pdf

Diez, J., Gatt, S., \& Racionero, S. (2011). Placing immigrant and minority family and community members at the school's centre: The role of community participation. European Journal of Education, 46(2), 184-196.

Engel, S. (2006). Narrative analysis of children's experience. In S. Greene \& D. Hogan (Eds.), Researching children's experience (pp. 200-2016). Sage Publications. doi:10.4135/9781849209823

Epstein, J. (2009). School, family and community partnerships. Your handbook for action (3rd ed.). Corwin Press.

Fargas-Malet, M., McSherry, D., Larkin, E., \& Robinson, C. (2010). Research with children: Methodological issues and innovative techniques. Journal of Early Childhood Research, 8, 175-192.

Farrell, A., Kagan, S. L., \& Tisdall, E. K. M. (2016). The Sage handbook of early childhood research. Sage.

Gatt, S., Ojala, M., \& Soler, M. (2011). Promoting social inclusion with everyone: Learning communities and INCLUD-ED. International Studies in Sociology of Education, 21(1), 33-47.

Gordon, T., Lahelma, E., \& Tolonen, T. (2002). Katseelta piilossa. Hiljaisuus ja liikkumattomuus kouluetnografin havainnoissa. In S. Aaltonen \& P. Honkatukia (Eds.), Tulkintoja tytöistä (pp. 305-325). Suomalaisen Kirjallisuuden Seura.

Hakomäki, H. (2012). Storycomposing in music therapy. A collaborative experiment with a young co-researcher. In G. Trondalen \& K. Stensæth (Eds.), Barn, musikk, helse (pp. 147-171). NMH-publikasjoner.

Hakomäki, H. (2013). Storycomposing as a path to a child's inner world. A collaborative music therapy experiment with a child co-researcher (doctoral dissertation). Jyväskylä Studies in Humanities 204, University of Jyväskylä, Finland.

Hakomäki, H., \& Karlsson, L. (in press). Child perspective in practice; A child as a coresearcher in a music psychotherapy research.Journal of Music Therapy.

Hart, R. (1992). Children's participation. From Tokenism to citizenship (Innocenti Essays No. 4). UNICEF.

Hart, R. A. (1995). The right to play and children's participation. In H. Shier (Eds.), The article 31 action pack. Play-Train.

Hayball, F., McCrorie, P., Kirk, A., Gibson, A. M., \& Ellaway, A. (2018). Exploring children's perceptions of their local environment in relation to time spent outside. Children and Society, 32, 14-26. doi:10.1111/chso.12217

Hohti, R. (2016). Classroom matters: Research with children as entanglement (doctoral dissertation). Opettajankoulutuslaitos, julkaisuja; No. 387 . http://urn.fi/URN:ISBN: 978-951-51-2069-4 
Hohti, R., \& Karlsson, L. (2013). Lollipop stories: Listening to children's voices in the classroom and narrative ethnographical research. Childhood, 1-15. doi:10.1177/ o907568213496655

Hohti, R., Paakkari, A., \& Stenberg, K. (2019). Leaping and dancing with digitality: Exploring human-smartphone-entanglements in classrooms. In P. Rautio \& E. Stenvall (Eds.), Social, material and political constructs of arctic childhoods (pp. 85-102). Springer.

Hohti, R., \& Tammi, T. (2020). The greenhouse effect: Multispecies childhood and noninnocent relations of care. Childhood, 26(2), 169-185. doi:10.1177/ogo7568219826263

Honkanen, K., Poikolainen, J., \& Karlsson, L. (2018). Children and young people as coresearchers. Researching subjective well-being in residential area with visual and verbal methods. Children's Geographies, 16(2), 184-195. doi:10.1080/ 14733285.2017.1344769

Honkanen, K., Poikolainen, J., \& Karlsson, L. (in press). Well-being places: Children's and young people's experiences of subjective well-being, social relations, emotions and action. Children's Geographies.

Hummelstedt-Djedou, I., Zilliacus, H., \& Holm, G. (2018). Diverging discourses on multicultural education in Finnish teacher education programme policies: Implications for teaching. Multicultural Education Review, 10(3), 184-202.

Hynynen, S.-T., \& Hankonen, N. (2015). Autonomiaa tukien aktiivisemmaksi? Itsemääräämisen teoria lasten ja nuorten liikunnan edistämisessä [Supporting Autonomy to Create a More Active Adolescence? Applying Self-Determination Theory in Increasing Adolescent Physical Activity]. Kasvatus, 46(5), 473-487.

Hytönen, J. (2008). Lapsikeskeisen kasvatuksen ydinkysymyksiä. WSOY.

Hyvärinen, R. (2014). Paikan käsitykset paikkalähtöisen kasvatuksen tutkimuksessa. In E. Estola, M. Hiltunen, \& E. K. Hyry-Beihammer (Eds.), Paikkaja kasvatus (pp. 9-30). Lapin yliopistokustannus.

Isola, A.-M., Kaartinen, H., Leemann, L., Lääperi, R., Schneider, T., Valtari, S., \& Keto-Tokoi, A. (2017). Mitä osallisuus on? Osallisuuden viitekehystä rakentamassa (THL: TYÖPAPERI 33/2O17). http://urn.fi/URN:ISBN:978-952-302-917-O

James, A., \& James, A. (2008). Key concepts in childhood studies. Sage Publications. James, A., Jenks, C., \& Prout, A. (1998/1999). Theorizing childhood. Polity Press. Jørgensen, P. S., \& Kampmann, J. (2000). Børn som informanter. Børnerådet.

Kangas, J. (2016). Enhancing children's participation in early childhood education through the participatory pedagogy. Department of Teacher Education, Faculty of Behavioral Science, University of Helsinki. https://helda.helsinki.fi/bitstream/ handle/10138/159547/enhancin.pdf?sequence=1\&isAllowed $=y$

Kangas, J., \& Lastikka, A.-L. (2019). Children's initiatives in the Finnish early childhood education context. In S. Garvis, H. Harju-Luukkainen, S. Sheridan, \& P. Williams (Eds.), Nordic families, children and early childhood education (pp. 15-36). Palgrave Macmillan. 
Karlsson, L. (2005). Lapset tiedon ja kulttuurin tuottajina [Children as informants and knowledge actors]. In S. Hänninen, J. Karjalainen, \& T. Lahti (Eds.), Toinen tieto. Kirjoituksia huono-osaisuuden tunnistamisesta (pp. 173-194). Sosiaali- ja terveysalan tutkimus- ja kehittämiskeskus.

Karlsson, L. (2010). Lapsinäkökulmainen tutkimus ja aineiston tuottaminen [The child perspective study and data collection]. In K. P. Kallio, A. Ritala-Koskinen, \& N. Rutanen (Eds.), Missä lapsuutta tehdään? (pp. 121-141). Nuorisotutkimusseura. Verkkojulkaisuja 106. http://www.nuorisotutkimusseura.fi/images/julkaisuja/ missa_lapsuutta_tehdaan.pdf

Karlsson, L. (2012a). Lapsinäkökulmaisen tutkimuksen ja toiminnan poluilla [The child perspective study and action]. In L. Karlsson \& R. Karimäki (Eds.), Sukelluksia lapsinäkökulmaiseen tutkimukseen ja toimintaan [Diving into study and action on the child perspective] (pp. 17-63). Suomen kasvatustieteellinen seura, Jyväskylän yliopistopaino.

Karlsson, L. (2012b). Lapset toimivat - aikuiset valistavat: lasten kertomuksia syömisestä [Children act - Adults enlighten]. In L. Karlsson \& R. Karimäki (Eds.), Sukelluksia lapsinäkökulmaiseen tutkimukseen ja toimintaan [Diving into study and action on the child perspective] (pp. 235-283). Suomen kasvatustieteellinen seura, Jyväskylän yliopistopaino.

Karlsson, L. (2013). Storycrafting method-to share, participate, tell and listen in practice and research. The European Journal of Social \& Behavioural Sciences, 6(3), 11091117. http://www.futureacademy.org.uk/files/menu_items/other/ejsbs88.pdf

Karlsson, L. (2014). Children's voices in context of art education and circumstances for interaction. In I. Ruokonen \& H. Ruismäki (Eds.), Voices for tomorrow: Sixth international journal of intercultural arts education (pp. 25-34). University of Helsinki, Department of Teacher Education. http://hdl.handle.net/10138/44696

Karlsson, L., \& Karimäki, R. (2012). Sukelluksia lapsinäkökulmaiseen tutkimukseen ja toimintaan [Diving into study and action on the child perspective]. Suomen kasvatustieteellinen seura, Jyväskylän yliopistopaino.

Karlsson, L., Lähteenmäki, M., \& Lastikka, A.-L. (2019). Increasing well-being and giving voice through storycrafting to children who are refugees, immigrants, or asylum seekers. In J.-A. Aerila \& K. J. Kerry-Moran (Eds.), Story in children's lives: Contributions of the narrative mode to early childhood development, literacy, and learning (pp. 29-53). Springer International. https://doi.org/10.1007/978-3-O30-19266-2_3

Karlsson, L., Weckström, E., \& Lastikka, A-L. (2018). Osallisuuden toimintakulttuuria rakentamassa sadutusmenetelmällä [Building a Culture of Participation through Storycrafting]. In J. Kangas, J. Vlasov, E. Fónsen, \& J. Heikka (Eds.), Osallisuuden pedagogiikkaa varhaiskasvatuksessa 2 - Suunnittelu, toteuttaminen ja kehittäminen [Participatory Pedagogy in Early Childhood Education 2 - Planning, Implementing and Developing Practices] (pp. 73-99). Suomen Varhaiskasvatusry. 
Kavanagh, D. J., \& Bower, G. H. (1985). Mood and self-efficacy: Impact of Joy amd sadness on perceived capabilities. Cognitive Therapy and Research, 9(5), 507-525.

Kennedy, D. (2006). The well of being. Childhood, subjectivity and education. State University of New York Press.

Kiili, J. (2006). Lasten osallistumisen voimavarat. Tutkimus Ipanoiden osallistumisesta. In Studies in education, psychology and social research. Jyväskylän yliopisto.

Kinnunen, S., \& Einarsdóttir, J. (2017). “Look mother! Mother look!” Young children exploring life with their mother. In M. Narey (Ed.), Multimodal perspectives of language, literacy, and learning in early childhood. Educating the young child (Advances in Theory and Research, Implications for Practice, Vol. 12, pp. 109-126). Springer International. https://doi.org/10.1007/978-3-319-44297-6_6

Kjær, B. (2015). Children as co-researchers. Arv: Nordic yearbook of folklore, 71, 189-192. Koskelainen, J. (2017). Mahtava minä. Itsekkyyden voima ja vastavoimat. Atena.

Lähteenmäki, M. (2013). Lapsi turvapaikanhakijana: Etnografisia näkökulmia vastaanottokeskuksen ja koulun arjesta [The Child as an Asylum Seeker: Perspectives on Reception Centres and Daily School Life]. http://urn.fi/URN:ISBN:978-952-10-8205-4

Lee, N. (2001). Childhood and society. Growing up in an age of uncertainty. Open University Press.

Lewis, A., \& Lindsay, G. (2000). Researching children's perspectives. Open University Press.

Lundy, L., Mcevoy, L., \& Byrne, B. (2011). Working with young children as co-researchers: An approach informed by the United Nations Convention on the Rights of the Child. Early Education and Development: Children's Rights and Voices in Research: Cross-National Perspectives, 22(5), 714-736. doi:10.108o/10409289.2011.596463

Martela, F., \& Richard, R. (2015). The benefits of benevolence: Basic psychological needs, beneficence, and the enhancement of well-being. Journal of Personality, $84(6), 75^{\circ}-764$.

Mikkeli, H., \& Pakkasvirta, J. (2007). Tieteiden välissä? Johdatus monitieteisyyteen, tieteidenvälisyyteen ja poikkitieteisyyteen. WSOY.

Olli, J., Vehkakoski, T., \& Salanterä, S. (2012). Facilitating and hindering factors in the realization of disabled children's agency in institutional contexts - Literature review. Disability \& Society, 27(6), 793-807. doi:10.108o/o9687599.2012.679023

Olli, J., Vehkakoski, T., \& Salanterä, S. (2014). The habilitation nursing of children with developmental disabilities - Beyond traditional nursing practices and principles? International Journal of Qualitative Studies on Health and Well-being, 9(1). doi:10.3402/qhw.v9.23106

Piipponen, O., \& Karlsson, L. (2019). Children encountering each other through storytelling: Promoting intercultural learning in schools. The Journal of Educational Research.

Prout, A. (2005). The future of childhood. Towards the interdisciplinary study of children. Routledge Falmer. 
Qvortrup, J., Corsaro, W. A., \& Honig, M.-S. (2009). The Palgrave handbook of childhood studies. Palgrave Macmillan.

Rainio, A. P. (2010). Lionhearts of the playworld: An ethnographic case study of the development of agency in play pedagogy (doctoral dissertation). University of Helsinki, Institute of Behavioural Sciences Studies in Educational Sciences, 233. http://urn.fi/ URN:ISBN:978-952-10-5959-9

Raittila, R. (2008). Retkellä. Lasten ja kaupunkiympäristön kohtaaminen. Jyväskylä Studies in Education, Psychology and Social Research, 333.

Raivio, H., \& Karjalainen, J. (2013). Osallisuus ei ole keino tai väline, palvelut ovat! Osallisuuden rakentuminen 2010-luvun tavoite- ja toimintaohjelmissa. In T. Era (Ed.), Osallisuus - oikeutta vai pakkoa? (pp. 12-34). Jyväskylän ammattikorkeakoulun julkaisuja, No. 156. University of Jyväskylä.

Rautio, P., Hohti, R., Leinonen, R.-M., \& Tammi, T. (2017). Shitgulls and shops are nature: Urban child-within-nature reconfigurations. Environmental Education Research, 23(10), 1379-139o.

Riihelä, M. (2000). Leikkivät tutkijat. Edita.

Rutanen, N. (2007). Two-year-old children as co-constructors of culture. European Early Childhood Education Research Journal, 15(1), 59-69. doi:10.1080/13502930601161825

Ryan, R. M., \& Deci, E. L. (2017). Self-determination theory: Basic psychological needs in motivation, development, and wellness. Guilford Publishing.

Rytioja, M., Lappalainen, K., \& Savolainen, H. (2019). Behavioural and emotional strengths of sociometrically popular, rejected, controversial, neglected, and average children. European Journal of Special Needs Education, 1(7), 1-15.

https://doi-org.ezproxy.uef.fi:2443/10.108o/o8856257.2018.15606o7

Schunk, D. K. (2003). Self-efficacy for reading and writing: Influence of modeling, goalsetting, and self-evaluation. Reading and Writing Quarterly, 19(2), 159-172. doi:10.108o/ 10573560308219

Shier, H. (2001). Pathways to participation: Openings, opportunities and obligations. A new model for enhancing children's participation in decision-making, in line with article 12.1 The United Nations Convention on the Rights of the Child. Children \& Society, 15. https://ipkl.gu.se/digitalAssets/1429/1429848_shier20o1.pdf

Soja, E. (1996). Thirdspace. Journey to Los Angeles and other real-and-imagined places. Blackwell.

Sommer, D., Samuelsson, I. P., \& Hundeide, K. (2010). Child perspectives and children's perspectives in theory and practice. Springer.

Stenvall, E. (2009). "Sellast ihan tavallist arkee" Helsinkiläisten 3.-6.-luokkalaisten arki ja ajankäyttö. Helsingin kaupungin tietokeskus. http://www.hel2.fi/tietokeskus/ julkaisut/pdf/uudet_julkaisut_2oog.pdf

Tammi, T. (2017). Poliittinen prosessi ja demokratiakokeilujen tartunnat koulun arjessa [The political process and the contagions of democratic experiments in every-day life 
in school] (Doctoral dissertation). Helsinki Studies in Education, No. 2. Faculty of Educational Sciences, University of Helsinki.

Tammi, T. (2019). Breathing well at the wastelands? Indoor climate change in schools and the daily lives of arctic children. In P. Rautio \& E. Stenvall (Eds.), Social, material and political constructs of arctic childhoods - An everyday life perspective (pp. 17-34). Springer International.

Tammi, T. (2020). What if schools were lively more-than-human agencements all along? Troubling environmental education with moldschools. Environmental Education Research. doi:10.1080/13504622.2019.1584881

Thomson, F. (2007). Are methodologies for children keeping them in their place? Children's Geographies, 5(3), 207-218.

Tisdall, K., Cree, V. E., Davis, J., \& Gallagher, M. (2009). Researching with children and young people: Research design, methods and analysis. Sage.

Tuovila, A. (2003). "Mä soitan ihan omasta ilosta!" Pitkittäinen tutkimus 7-13-vuotiaiden lasten musiikin harjoittamisesta ja musiikkiopisto-opiskelusta (doctoral dissertation). Sibelius Academy, Helsinki.

Turja, L. (2016). Model of children's participation in ECEC. https://www.researchgate.net/ publication/316895844_Model_of_children\%27s_participation_in_ECEC

United Nations. (1989). Convention on the Rights of the Child (UNCRC). Author. https://www.ohchr.org/en/professionalinterest/pages/crc.aspx

Venninen, T., \& Leinonen, J. (2013). Developing children's participation through research and reflective practices. Asia-Pacific Journal of Research in Early Childhood Education, 7(1), 31-49.

Virkki, P. (2015). Varhaiskasvatus toimijuuden ja osallisuuden edistäjänä (Doctoral dissertation). Dissertations in Education, Humanities, and Theology, University of Eastern Finland.

Vuorisalo, M., Rutanen, N., \& Raittila, R. (2015). Constructing relational space in early childhood education. Early Years, 35(1), 67-79. doi:10.108o/o9575146.2014.985289

Weckström, E., Jääskeläinen, V., Ruokonen, I., Karlsson, L., \& Ruismäki, H. (2017). Steps together - Children's experiences of participation in club activities with the elderly. Journal of Intergenerational Relationships, 15(3), 273-289. doi:10.108o/ 15350770.2017.1330063

Weckström, E., Karlsson, L., Pöllänen, S., \& Lastikka, A.-L. (in press). Creating a participatory culture: Early childhood education and care educators in the face of change.

Wentzel, K. R., Donlan, A., \& Morrison, D. (2012). Peer relationships and social motivational processes. In G. W. Ladd \& A. M. Ryan (Eds.), Peer relationships and adjustment at school (pp. 79-107). Information Age Publishing.

Zhou, V. X., \& Pilcher, N. (2019). Revisiting the 'third space' in language and intercultural studies. Language and Intercultural Communication, 19(1), 1-8. 